\title{
OJAČANJE ARMIRANOBETONSKIH NOSAČA POMOĆU FRP-A - U SKLADU S EN 1992-1-1
}

\section{Tomislav Kišiček}

Sveučilište u Zagrebu, Građevinski fakultet, docent

Kristijan Pavić

Sveučilište u Zagrebu, Građevinski fakultet, mag.ing.građ

Sažetak: Poboljšanje načina ojačanja i popravaka postojećih objekata već duže vrijeme privlači pozornost inženjera građevinarstva. Sve se više razvijaju i proučavaju vlaknima armirani polimeri, tj. FRP sustavi (FRP engl. Fibre Reinforced Polymers) koji služe kao materijal za ojačavanje konstrukcija. Ubrajaju se u kompozitne materijale jer se sastoje od polimerne matrice $i$ armaturnih vlakana. $U$ ovome radu prikazan je proračun ojačavanja armiranobetonskih nosača pomoću FRP-a u skladu s novim normama EN 1992-1-1. Proračuni, u skladu s prednormom ENV 1992-1-1, prikazani u "fib bulletin 14 - Externally boded FRP reinforcement for RC structures", služili su kao temelj ovom radu.

Ključne riječi: armirani beton, FRP, ojačanje, proračun

\section{STRENGTHENING OF REINFORCED CONCRETE GIRDERS WITH FRP - ACCORDING TO EN 1992-1-1}

\begin{abstract}
Improvement of strengthening and repairing of existing structures is in focus of civil engineers for a long time. More and more, fiber reinforced polymers i.e. FRP systems are studied, developed and used as strengthening material. They are composite materials because they consists of polymer matrix and fibers. In this paper, the calculation of strengthening of reinforced concrete girders with FRP, according to EN 1992-1-1 is shown. Calculations shown in Fib bulletin 14 - Externally boded FRP reinforcement for RC structures, according to ENV 1992-1-1 are used as a base for this paper.
\end{abstract}

Key words: reinforced concrete, FRP, strengthening, calculation 


\section{Uvod}

U nas i u svijetu postoji potreba za popravcima i ojačanjima postojećih konstrukcija kako bi im se produljio uporabni vijek. Poboljšanje načina ojačanja i popravaka postojećih objekata već duže vrijeme privlači pozornost inženjera građevinarstva. Uz mnoge metode ojačanja konstrukcija, posljednjih desetljeća primjenjuju se vlaknima armirani polimeri, tj. FRP. To su kompozitni materijali koji se sastoje od polimerne matrice i armaturnih vlakana. Za izradu matrice najviše se koriste epoksidne, nezasićene poliesterske, vinilesterske, bismelamidne i cianat esterske smole, dok su vlakna najčešće staklena $(G)$, aramidna $(A)$ ili ugljična $(C)$ pa se tako razlikuju proizvodi od GFRP-a, AFRP-a te CFRP-a.

FRP sustavi danas nalaze posebno mjesto unutar kompozitnih materijala zbog svojih prednosti, kao što su: otpornost na koroziju, visoka vlačna čvrstoća, dobro ponašanje pod dinamičkim djelovanjem (proizvodi od ugljičnih vlakana), otpornost na većinu lužina i kiselina, mogućnost prigušenja vibracija te izrazito dobar odnos čvrstoće i vlastite težine (40-50 puta veći nego kod čelika). Osim prednosti, proizvodi od FRP-a imaju i nedostatke kao što su: elastično ponašanje do sloma, malo istezanje pri slomu (osobito kod proizvoda od ugljičnih vlakana), te velika razlika u svojstvima uzduž i poprijeko na smjer pružanja vlakana, slom zbog popuštanja pod dugotrajnim naprezanjima (zbog smanjene čvrstoće pod dugotrajnim djelovanjem). Glavni nedostatak je da takvi proizvodi nisu duktilni.

Zbog različitih situacija u kojima se FRP može koristiti, razvijeno je nekoliko tipova FRP ojačanja koji se mogu podijeliti u sljedeće kategorije: a) „Wet lay-up“ sustavi (sustavi s mokrim polaganjem) - tkanine od FRP-a koje se lijepe na podlogu, b) prefabricirani FRP sustavi - lijepljenje lamela od FRP-a na podlogu i c) specijalni FRP sustavi - sustavi s automatskim ovijanjem, prednapete FRP trake, umetnute FRP trake. Također postoje i šipke od FRP-a kojima se, umjesto čeličnim šipkama, mogu armirati konstrukcije.

U sastavu "Međunarodne organizacije za beton u konstrukcijama" - fib, nalazi se radna skupina 9.3 pod nazivom „FRP armatura za betonske konstrukcije“ koja ima zadatak izraditi preporuke za proračun armiranobetonskih konstrukcija, ojačanih ili armiranih FRP armaturom u skladu s Model propisima i Eurokodom 2. U publikaciji pod nazivom „fib bulletin 14 - Externally boded FRP reinforcment for RC structures" [1] dane su preporuke proračuna u skladu s prednormom ENV 1992-1-1. Ti proračuni i preporuke poslužile su kao temelj proračunima i preporukama prikazanima u ovom radu koji su napravljeni u skladu s novim normama EN 1992-1-1 [2], [3], [4].

\section{Osnove proračuna ojačanja}

\subsection{Općenito}

Ojačanje armiranobetonskih konstrukcija pomoću FRP oslanja se na kompozitnu vezu između armiranog betona i vanjskog ojačanja. Stanje elementa prije ojačanja ima veliki utjecaj na kvalitetu ojačanja (npr. prisutnost korozije na armaturi) te je u mnogo slučajeva potrebno prvo izvršiti popravke na elementu koji se planira ojačati.

Proračun ojačanja potrebno je provesti prema graničnom stanju nosivosti te graničnom stanju uporabljivosti koje u mnogim slučajevima može biti mjerodavno za određivanje potrebne površine ojačanja. Potrebno je razmotriti sljedeće proračunske situacije: a) stalna proračunska situacija (pri normalnim uvjetima uporabe konstrukcije), b) izvanredna proračunska situacija (požar, udar vozila, vandalizam), te c) specijalni slučaj opterećenja (cikličko opterećenje, otpornost na požar, otpornost na udar).

Također je potrebno posvetiti pozornost različitim oblicima sloma koji se mogu pojaviti. Ojačanje je potrebno projektirati na način da se izbjegnu krti lomovi, tj. potrebno je osigurati dovoljno popuštanje armaturnog čelika kako bi se osigurao duktilni lom konstrukcije. Oblici sloma mogu se podijeliti na sljedeći način: a) slom zbog popuštanja armature i sloma FRP-a, b) slom zbog popuštanja armature i sloma betona prije nego što dođe do sloma FRP-a, c) slom zbog drobljenja betona prije popuštanja čelika i d) slom zbog gubitka kompozitnog djelovanja. Navedeni oblici sloma mogu se jednostavno podijeliti na one s punim kompozitnim djelovanjem (oblici sloma a, b i c) te na one koji se događaju zbog gubitka kompozitnog djelovanja (oblik sloma d). Pri proračunu graničnih stanja nosivosti i uporabivosti potrebno je uzeti u obzir navedene oblike sloma. 


\subsection{Proračun prema graničnom stanju nosivosti}

S obzirom na oblike sloma, FRP sustavi se dijele na one kod kojih je prisutna puna spregnuta veza između betona i FRP-a i na one kod kojih zbog određenih razloga može doći do odvajanja FRP-a i betona. U sustavima kod kojih je prisutna puna spregnuta veza između betona i FRP-a, ovisno o razredu betona, pretpostavlja se proračunski dijagram betona prikazan na slici 1a).

Proračunska tlačna čvrstoća betona prema EN 1992-1-1 [2] određuje se prema izrazu:

$$
f_{\mathrm{cd}}=\alpha_{\mathrm{cc}} \cdot f_{\mathrm{ck}} / \gamma_{\mathrm{c}}
$$

gdje je:

$\alpha_{\mathrm{cc}}$ - koeficijent koji u obzir uzima dugotrajne učinke na tlačnu čvrstoću i nepovoljne učinke kao posljedicu načina opterećivanja. Prema hrvatskom nacionalnom dodatku, prihvaća se vrijednost $\alpha_{\mathrm{cc}}=1,0$

$f_{\text {ck }}$ - karakteristična vrijednost tlačne čvrstoće betona

$\gamma_{C}$ - parcijalni koeficijent sigurnosti za beton, $\gamma_{C}=1,5$.

Proračunski dijagrami armaturnog čelika i FRP-a prikazani su na slici 1b). Proračunska granica popuštanja čelika za armiranje $f_{\text {yd }}$ određuje se kao:

$$
f_{\mathrm{yd}}=f_{\mathrm{yk}} / \gamma_{\mathrm{s}}
$$

gdje je:

$f_{\mathrm{yk}}$ - karakteristična vrijednost granice popuštanja čelika

$\gamma_{S}$ - parcijalni koeficijent sigurnosti za čelik, $\gamma_{S}=1,15$
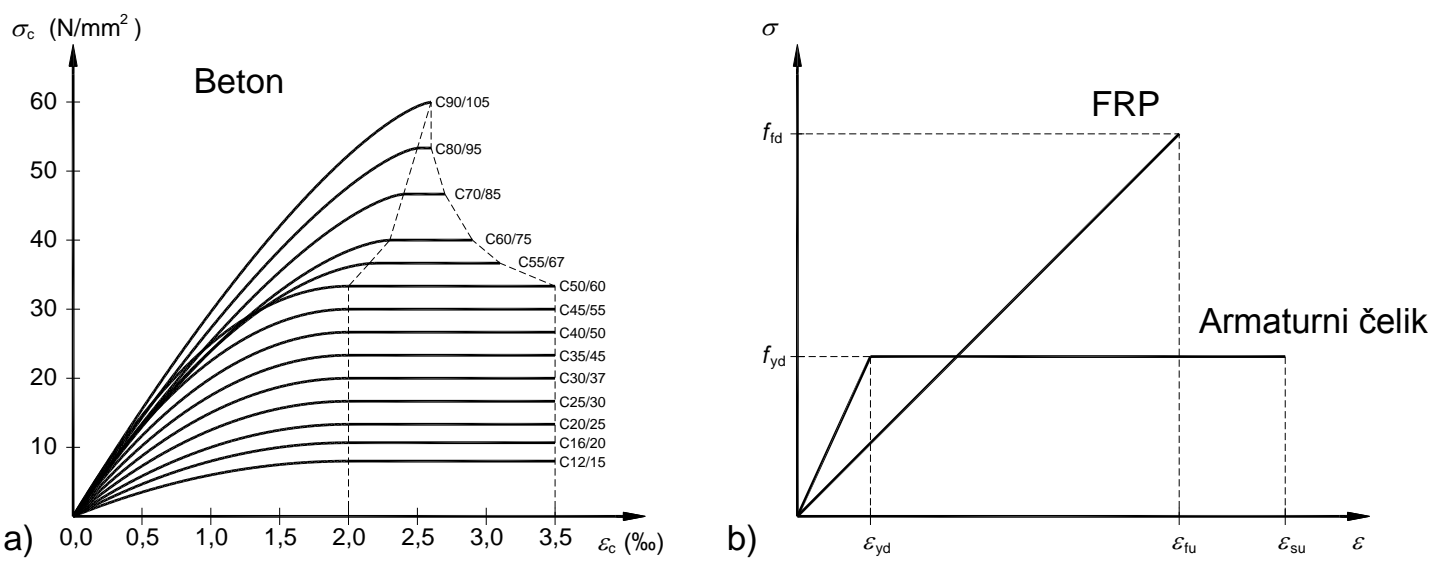

Slika 1 - Proračunski dijagram betona, armaturnog čelika i FRP-a

Proračunska vlačna čvrstoća FRP-a $f_{\mathrm{fd}}$ može se odrediti pomoću sljedećeg izraza:

$$
f_{\mathrm{fd}}=\frac{f_{\mathrm{fk}}}{\gamma_{\mathrm{f}}} \cdot \frac{\varepsilon_{\text {fue }}}{\varepsilon_{\text {fum }}}
$$


gdje je:

$f_{\text {fk }}$ - karakteristična vrijednost vlačne čvrstoće FRP-a

$\gamma_{\mathrm{f}}$ - parcijalni koeficijent sigurnosti za FRP

$\varepsilon_{\text {fue }}$ - efektivna relativna deformacija FRP-a

$\varepsilon_{\text {fum }}$ - srednja relativna deformacija FRP-a

$\varepsilon_{\text {fue }} / \varepsilon_{\text {fum }}=1,0$ - prema preporukama iz fib Bulletin 14 [1].

Iz slike 1b) je vidljivo da se odnos naprezanja i deformacija za FRP može pretpostaviti kao linearan te se takav odnos može prikazati koristeći sljedeći izraz:

$$
\sigma_{\mathrm{f}}=E_{\mathrm{fu}} \cdot \varepsilon_{\mathrm{f}} \leq f_{\mathrm{fd}}
$$

gdje je:

$$
E_{\mathrm{fu}}=f_{\mathrm{fk}} / \varepsilon_{\mathrm{fuk}}
$$

Pri proračunu graničnog stanja nosivosti, pod pretpostavkom pune spregnute veze između betona i FRP-a, koriste se koeficijenti sigurnosti materijala $\gamma_{\mathrm{f}}$ navedeni u tablici 1. Pod pojmom "Tip A“ podrazumijeva se prefabricirani FRP sustav $s$ normalnom kontrolom kvalitete ili sustav mokrim polaganjem $\mathrm{s}$ visokom kontrolom kvalitete proizvodnje i ugradnje, dok „Tip B“ podrazumijeva sustav s normalnom kontrolom kvalitete ili bilo koji sustav pod teškim uvjetima ugradnje.

\section{Tablica 1 - Koeficijenti sigurnosti FRP materijala [1]}

\begin{tabular}{|c|c|c|}
\hline Vrsta FRP-a & Tip A & Tip B \\
\hline CFRP & 1,20 & 1,35 \\
\hline AFRP & 1,25 & 1,45 \\
\hline GFRP & 1,30 & 1,50 \\
\hline
\end{tabular}

Potpuno narušavanje veze između betona i FRP-a moguće je zbog više razloga. Ipak, pod pretpostavkom pravilnog načina postavljanja FRP-a te korištenja primjerenih i od strane proizvođača odobrenih materijala, do odvajanja će doći zbog pojave sloma u betonu. Pri proračunu graničnog stanja nosivosti uvodi se faktor sigurnosti betona $\gamma_{c b}=1,5$. U određenim slučajevima, npr. kod korištenja betona vrlo visoke čvrstoće, može se dogoditi da posmična čvrstoća betona iznosi više od posmične čvrstoće ljepila. Zbog toga se pri proračunu graničnog stanja nosivosti uvodi faktor sigurnosti za ljepilo $\gamma_{\mathrm{a}}=1,5$.

\subsection{Proračun prema graničnom stanju uporabivosti}

Proračunom prema graničnom stanju uporabivosti potrebno je dokazati da konstrukcija koja je ojačana FRP-om može obavljati sve funkcije tijekom svog životnog vijeka. Zato se provjerava: a) ograničenje naprezanja (kako bi se izbjeglo puzanje i oštećenje betona te puzanje i lom FRP-a), b) ograničenje progiba (koji mogu ograničiti uobičajenu uporabu konstrukcije te imati negativan estetski utjecaj), c) ograničenje pukotina (koje mogu narušiti trajnost konstrukcije te uzrokovati slabljenje veze između FRP-a i betona).

Pri proračunu prema graničnom stanju uporabivosti može se pretpostaviti linearan odnos naprezanja i deformacija materijala koji sudjeluju u ojačanju te se koristi faktor sigurnosti materijala $\gamma_{M}=1$. Kod FRP-a, odnos naprezanja i relativnih deformacija može se prikazati sljedećim izrazom:

$$
\sigma_{\mathrm{f}}=E_{\mathrm{fk}} \cdot \varepsilon_{\mathrm{f}}
$$


gdje je: $E_{\mathrm{fk}}$ - karakteristična vrijednost sekantnog modula elastičnosti.

U mnogo slučajeva ojačanja granično stanje uporabivosti može biti mjerodavno za izbor površine i tipa ojačanja. Zbog izrazito velike čvrstoće materijala na bazi FRP-a često je za ostvarivanje nosivosti dovoljno koristiti malu površinu FRP-a, dok istovremeno tolika površina ne može zadovoljiti uvjete za granično stanje uporabivosti.

\subsection{Puno kompozitno djelovanje}

Pri punom kompozitnom djelovanju može se pretpostaviti da je FRP ispravno postavljen na unaprijed pripremljenu betonsku podlogu. Pri ovakvom načinu djelovanja do sloma dolazi zbog sloma samih materijala (čelik, beton i FRP), a ne zbog nedostatka zajedničkog djelovanja spomenuth materijala. Slom zbog popuštanja armature i sloma FRP-a javlja se u elementima s izrazito visokim razredima betona. Najčešći oblik sloma kod sustava s punim kompozitnim djelovanjem jest slom zbog popuštanja armature i sloma betona. Zbog toga što FRP ima izrazito veliku vlačnu čvrstoću i jer je to sustav s izrazito kvalitetnim materijalima, vrlo je malo slučajeva sloma FRP-a. Do sloma sustava također može doći i zbog drobljenja betona prije popuštanja čelika. Takav oblik sloma je nepoželjan jer je to krti oblik sloma. Moguće ga je izbjeći korištenjem duktilne armature. Zahtjevi za duktilnošću armature prikazani su u poglavlju 2.5 .

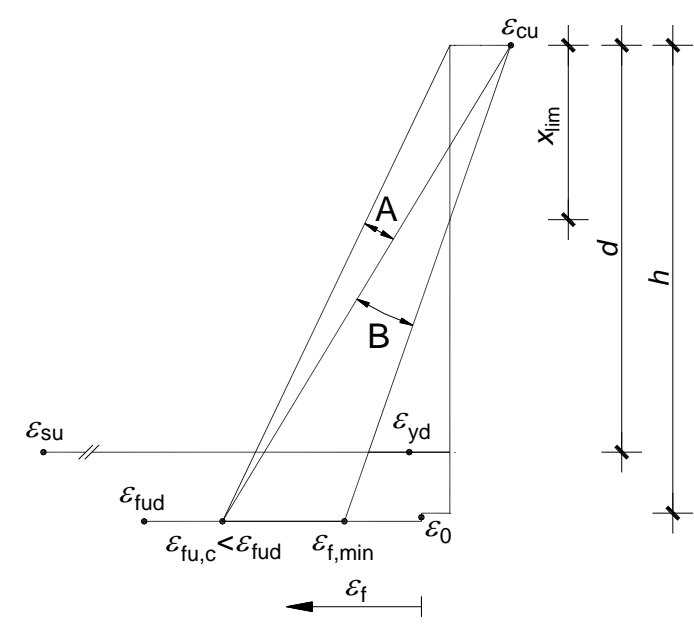

\section{Slika 2 - Raspored naprezanja po visini i oblici sloma}

Na slici 2 prikazana je raspodjela naprezanja po visini presjeka za granično stanje nosivosti i pripadni oblici sloma. Područje A predstavlja slom zbog popuštanja armature i sloma FRP-a, dok područje B predstavlja slom zbog popuštanja armature i sloma betona prije sloma FRP-a.

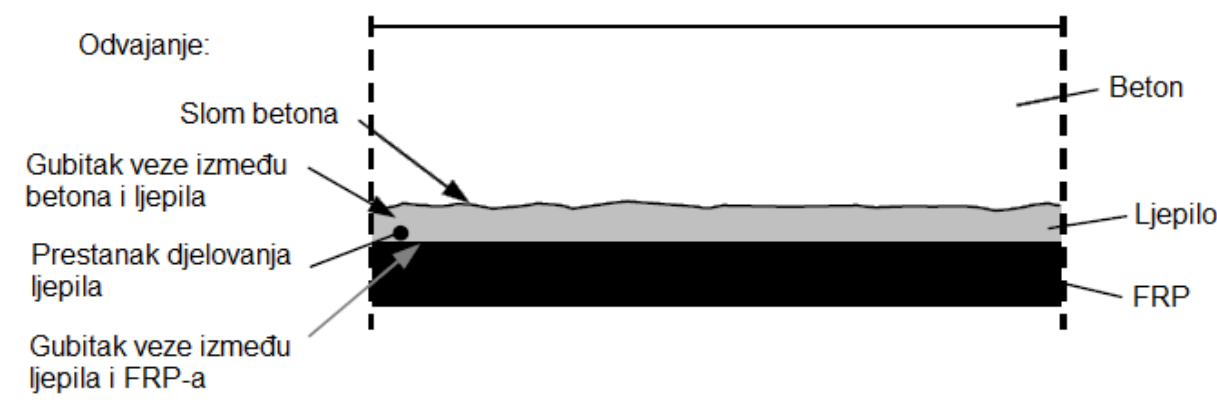

Slika 3 - Načini gubitka kompozitnog djelovanja 
Kompozitno djelovanje izrazito je važno pri prijenosu sila s betona u FRP. Zbog toga je potrebno uzeti u obzir gubitak kompozitnog djelovanja te različite oblike sloma koji se pri tome mogu pojaviti (slika 3). Na nekim dijelovima ojačanog sustava može se pojaviti i lokalni gubitak kompozitne veze. Najčešće se pojavljuje na mjestima pojave pukotina u betonu i zbog njega se ne mora nužno pojaviti neki od oblika sloma. Gubitak veze između ljepila i FRP-a dogodit će se jedino u slučaju kada površina betona nije primjereno pripremljena. Ljepilo na bazi epoksidne smole u većini slučajeva posjeduje veću posmičnu čvrstoću od betona te je zbog toga slom betona na kritičnim područjima najčešći oblik sloma pri gubitku kompozitnog djelovanja. U ovakvom slučaju sloma najčešće će doći do sloma površinskog sloja betona ili do sloma betona na liniji armature (slika 4).
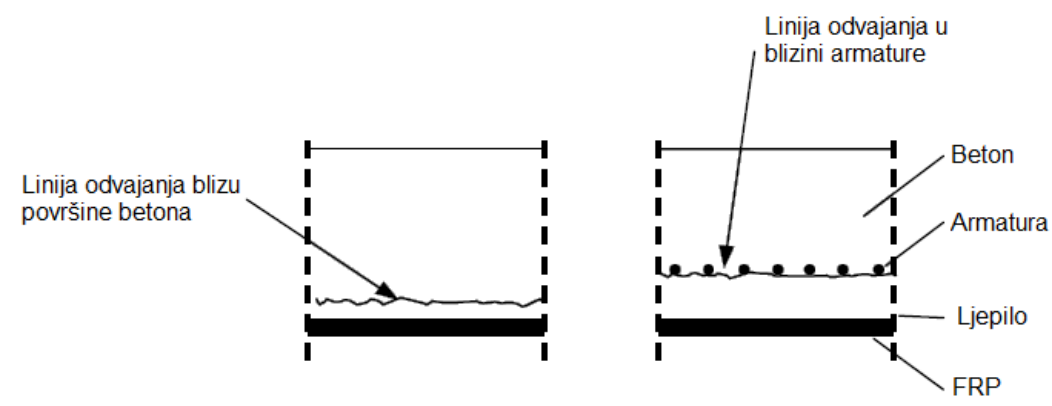

Slika 4 - Oblici sloma zbog odvajanja betona

\subsection{Duktilnost}

Pri ojačanju konstrukcijskih elemenata potrebno je obratiti pozornost na to da će ojačani element imati mnogo manji stupanj duktilnosti u odnosu na neojačani. Kako bi se osigurala njihova dostatna duktilnost potrebno je osigurati dovoljnu razinu popuštanja čelične armature. EN 1992-1-1 [5] daje sljedeće uvjete za određivanje graničnog koeficijenta visine tlačnog područja betona:
a) $\xi_{\lim }=x_{\mathrm{u}} / d=0,45$ za betone razreda $C \leq 50 / 60$
b) $\xi_{\lim }=x_{\mathrm{u}} / d=0,35$ za betone razreda $C \geq 55 / 67$

gdje je:

$x_{u}$ - maksimalna visina tlačnog područja betonskog presjeka

$d$ - statička visina betonskog presjeka.

$\mathrm{Na}$ temelju gore navedenih uvjeta za maksimalnu vrijednost koeficijenta visine tlačnog područja i odnosa prikazanih na slici 2, uz pretpostavku da je odnos visine i statičke visine elementa jednak $h / d=1,1$, može se proračunati relativna deformacija FRP-a u kritičnom presjeku ojačanog elementa te relativna vlačna deformacija čelične armature pri maksimalnoj veličini tlačnog područja.

Tablica 2 - Relativne deformacije FRPa i čelične armature u skladu s uvjetom maksimalne visine tlačnog područja

\begin{tabular}{|c|c|c|c|c|c|c|}
\hline $\begin{array}{l}\text { Razred } \\
\text { betona }\end{array}$ & $\mathrm{C} \leq 50 / 60$ & $\mathrm{C} 55 / 67$ & $\mathrm{C} 60 / 75$ & $\mathrm{C} 70 / 85$ & $\mathrm{C} 80 / 95$ & $\mathrm{C} 90 / 105$ \\
\hline$\varepsilon_{\mathrm{fu}, \mathrm{c}}$ & $0,0050-\varepsilon_{0}$ & $0,0044-\varepsilon_{0}$ & $0,0041-\varepsilon_{0}$ & $0,0038-\varepsilon_{0}$ & $0,0037-\varepsilon_{0}$ & $0,0037-\varepsilon_{0}$ \\
\hline$\varepsilon_{\mathrm{su}, \mathrm{c}}$ & 0,0043 & 0,0058 & 0,0054 & 0,0050 & 0,0048 & 0,0048 \\
\hline
\end{tabular}




\section{Proračun otpornosti ojačanog elementa na savijanje}

\subsection{Općenito}

Elementi od armiranog betona, prvenstveno opterećeni savijanjem, kao što su grede ili ploče, mogu se ojačati pomoću FRP sustava kako bi se povećala njihova otpornost na savijanje. Zbog toga je potrebno postaviti FRP na područje vlačnih naprezanja elemenata sa smjerom vlakanaca, paralelnim sa smjerom uzdužne osi elementa. Proračun se provodi pomoću već poznatih metoda proračuna koje se koriste kod armiranobetonskih konstrukcija, uz uvjet da je ispunjeno sljedeće: a) utjecaj FRP-a na nosivost potrebno je uzeti u obzir na primjeren način, b) potrebno je posvetiti posebnu pozornost na mogućnost odvajanja FRP-a i betona. Moguće je zanemariti proklizavanje između FRP-a i betona kod većine sustava gdje se koriste ljepila na bazi epoksidne smole koja se nanose na materijal debljinom od 1-1,5 mm.

\subsection{Početno stanje}

Prije određivanja potrebne površine FRP-a za ojačanje armiranobetonskog elementa potrebno je odrediti početno stanje elementa, tj. stanje elementa u trenutku ojačavanja. Moment savijanja u tom trenutku naziva se „početni moment" te se označava s $M_{0}$, a s obzirom da je u gotovo svim slučajevima opterećenja veći od momenta pri kojem dolazi do pojave prvih pukotina u elementu $M_{c r}$, u obzir se uzima raspucali poprečni presjek (vidjeti sliku 5). U slučajevima kada je $M_{0}<M_{\mathrm{cr}}$ može se zanemariti utjecaj početnog momenta pri proračunu ojačanja elementa na savijanje. Koeficijenti sigurnosti se uzimaju prema proračunu za granično stanje uporabivosti pa je tako koeficijent za stalno opterećenje $\gamma_{\mathrm{g}}=1,0$. Cilj provjere početnog stanja je pronalazak relativnih deformacija tlačnog ruba $\varepsilon_{\text {co }}$ poprečnog presjeka te relativnih deformacija vlačnog ruba poprečnog presjeka $\varepsilon_{0}$.

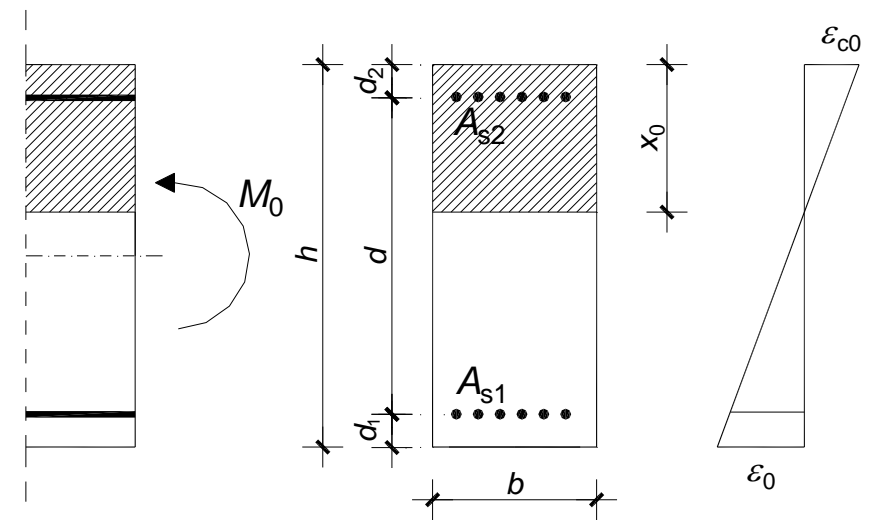

Slika 5 - Početno stanje poprečnog presjeka

Prema slici 5, položaj neutralne osi poprečnog presjeka može se odrediti pomoću sljedećeg izraza:

$$
\frac{1}{2} \cdot b \cdot x_{0}^{2}+\left(\alpha_{\mathrm{s}}-1\right) \cdot A_{\mathrm{s} 2} \cdot\left(x_{0}-d_{2}\right)=\alpha_{\mathrm{s}} A_{\mathrm{s} 1}\left(d-x_{0}\right)
$$

gdje je:

$\alpha_{\mathrm{s}}$ omjer momenata elastičnosti armature i betona $\alpha_{\mathrm{e}}=E_{\mathrm{s}} / E_{\mathrm{c}}$ 
Nakon što se iz izraza (7) odredi položaj neutralne osi poprečnog presjeka, moguće je odrediti relativne deformacije tlačnog i vlačnog ruba poprečnog presjeka. Relativna deformacija tlačnog ruba jest:

$$
\varepsilon_{\mathrm{c} 0}=\frac{M_{0} \cdot x_{0}}{E_{\mathrm{c}} \cdot I_{\mathrm{c} 0}}
$$

gdje je:

$M_{0}$ - početni moment

$x_{0}$ - položaj neutralne osi

$E_{\mathrm{c}}$ - modul elastičnosti betona

$I_{\mathrm{c} 0}$ - moment tromosti raspucanog poprečnog presjeka za početno stanje koji se dobije pomoću izraza:

$$
I_{\mathrm{c} 0}=\frac{b \cdot x_{0}^{3}}{3}+\left(\alpha_{\mathrm{s}}-1\right) \cdot A_{\mathrm{s} 2} \cdot\left(x_{0}+d_{2}\right)^{2}+\alpha_{\mathrm{s}} \cdot A_{\mathrm{s} 1} \cdot\left(d-x_{0}\right)^{2}
$$

Relativna deformacija vlačnog ruba poprečnog presjeka jest:

$$
\varepsilon_{0}=\varepsilon_{\mathrm{c} 0} \cdot \frac{h-x_{0}}{x_{0}}
$$

gdje je:

$h$ visina poprečnog presjeka.

\subsection{Otpornost na savijanje - granično stanje nosivosti}

\subsubsection{Proračun potrebnog ojačanja kod elemenata pravokutnog poprečnog presjeka}

Postupak proračuna potrebne površine FRP-a za ojačanje razlikuje se s obzirom na pretpostavljeni oblik sloma. Sljedeći izrazi i objašnjenja odnose se na najčešći oblik sloma - slom zbog popuštanja armature i sloma betona u tlačnom području prije sloma FRP lamele. Proračun za ovakav oblik sloma je moguće provesti ručno (bez iterativnog postupka), jer se iz ravnoteže poprečnog presjeka mogu proračunati relativna deformacija FRP lamele te njezina površina.

Iz dijagrama relativnih deformacija, uz poznatu relativnu deformaciju tlačnog ruba betona, $\varepsilon_{\text {cu2 }}$, iz sume momenata savijanja na donji rub betonskog presjeka (težište lamele i debljina lamele se zanemaruju), te uz zanemarivanje utjecaja tlačne armature iz slike 6 , može se odrediti izraz:

$$
M_{\mathrm{Ed}}=F_{\mathrm{c}} \cdot\left(h-k_{\mathrm{a}} \cdot \xi^{*} \cdot h\right)-A_{\mathrm{s} 1} \cdot f_{\mathrm{yd}} \cdot d_{1}
$$

gdje je:

$$
\begin{aligned}
& F_{\mathrm{c}}=f_{\mathrm{cd}} \cdot \alpha_{\mathrm{v}} \cdot b \cdot\left(\xi^{*} \cdot d\right) \\
& \xi^{*}=\left(\frac{\left|\varepsilon_{\mathrm{c}}\right|}{\left|\varepsilon_{\mathrm{c}}\right|+\left|\varepsilon_{0}\right|+\left|\varepsilon_{f}\right|}\right)
\end{aligned}
$$


$\mathrm{U}$ izrazima od (11) do (13) je: $\alpha_{\mathrm{v}}$ - koeficijent punoće proračunskog dijagrama betona; $k_{\mathrm{a}}$ - koeficijent položaja rezultante tlačnih naprezanja; $A_{\mathrm{s} 1}$ - površina čelične vlačne armature; $f_{\mathrm{yd}}$ - proračunska granica popuštanja čelika za armiranje; $d_{1}, d_{2}$ - udaljenost težišta vlačne, odnosno tlačne armature od donjeg, odnosno gornjeg ruba presjeka; $f_{c d}$ - proračunska tlačna čvrstoća betona; $M_{E d}$ - proračunski moment savijanja od djelovanja na ojačani presjek.

Koeficijent položaja rezultante tlačnih naprezanja, $k_{\mathrm{a}}$, te koeficijent punoće proračunskog dijagrama betona, $\alpha_{\mathrm{v}}$, ovisno o razredu betona, dani su u tablici 2 .

Tablica 2 - Vrijednosti koeficijenata $k_{\mathrm{a}}$ i $\alpha_{\mathrm{v}}$ s obzirom na razred betona [2]

\begin{tabular}{|l|c|c|c|c|c|c|}
\hline $\begin{array}{l}\text { Razred } \\
\text { betona }\end{array}$ & $C \leq 50 / 60$ & $\mathrm{C} 55 / 67$ & $\mathrm{C60/75}$ & $\mathrm{C70/85}$ & $\mathrm{C} 80 / 95$ & $\mathrm{C} 90 / 105$ \\
\hline $\begin{array}{l}\varepsilon_{\text {cu2 }} \\
(\% o)\end{array}$ & $-3,5$ & $-3,1$ & $-2,9$ & $-2,7$ & $-2,6$ & $-2,6$ \\
\hline$k_{\mathrm{a}}$ & 0,416 & 0,392 & 0,377 & 0,362 & 0,355 & 0,353 \\
\hline$\alpha_{\mathrm{v}}$ & 0,810 & 0,742 & 0,695 & 0,637 & 0,599 & 0,583 \\
\hline
\end{tabular}

Uvrštavanjem izraza (12) za silu $F_{\mathrm{c}}$ u izraz (11) za proračunski moment djelovanja $M_{\mathrm{Ed}}$, dobije se kvadratna jednadžba iz koje se kao rješenje dobije $\xi^{*}$. Nakon toga se proračunava relativna deformacija FRP lamele $\varepsilon_{\mathrm{f}}$ (vidjeti sliku 6).
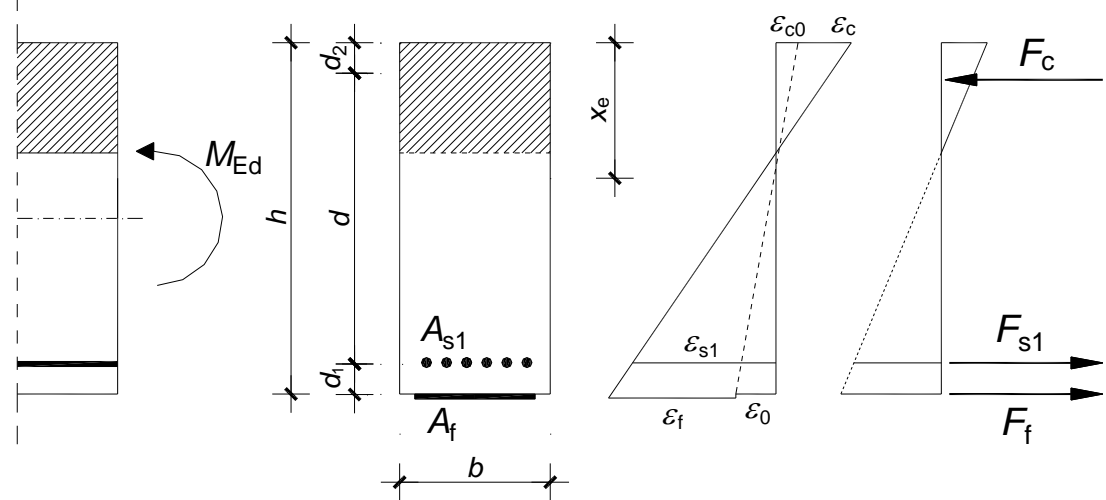

Slika 6 - Prikaz osnovnih komponenti proračuna grede ojačane FRP-om

Iz sume horizontalnih sila (slika 6) proračunava se potrebna površina FRP lamele za ojačanje:

$$
\begin{aligned}
& F_{\mathrm{f}}+F_{\mathrm{s} 1}=F_{\mathrm{c}} \\
& F_{c}-F_{\mathrm{s} 1}=F_{\mathrm{f}} \\
& A_{\mathrm{f}} \cdot \varepsilon_{\mathrm{f}} \cdot E_{\mathrm{fu}}=F_{\mathrm{c}}-F_{\mathrm{s} 1}
\end{aligned}
$$

Dakle, potrebna površina FRP lamele iznosi:

$$
A_{\mathrm{f}}=\frac{F_{\mathrm{c}}-F_{\mathrm{s} 1}}{\varepsilon_{\mathrm{f}} \cdot E_{\mathrm{fu}}}
$$

Ako gornjim proračunom relativna deformacija FRP lamele bude $\varepsilon_{\mathrm{f}}>\varepsilon_{\mathrm{fu}}$, tada treba proračunati slom $u$ kojem dolazi do popuštanja armature i sloma FRP lamele, a da ne dođe do sloma betona u tlačnom području. 
Takav proračun temelji se na istim pretpostavkama kao i prethodni proračun, no razlika je u tome što se tada mora pretpostaviti relativna deformacija FRP lamele, $\varepsilon_{\mathrm{f}}=\varepsilon_{\mathrm{fu}}$, a iz uvjeta ravnoteže se traži relativna deformacija tlačnog ruba betona. Kako o tlačnoj relativnoj deformaciji betona ovisi i proračun koeficijenta punoće radnog dijagrama $\alpha_{\mathrm{v}}$ te koeficijenta položaja težišta naprezanja u betonu $k_{\mathrm{a}}$, vrlo je teško jednoznačno izraziti relativnu deformaciju betona, tako da je lakše takav proračun riješiti uz pomoć računala. Proračun otpornosti na savijanje pri drugim oblicima sloma u ovome radu nije prikazan, jer su takvi oblici sloma rijetki te njihovo pojavljivanje ovisi o izvedbi konstrukcijskih detalja (čišćenje betonske podloge, korištenje odobrenih materijala), a manje o samom proračunu na otpornost.

Proračun potrebne površine FRP ojačanja za nosače T-presjeka gotovo je jednak gore prikazanom proračunu, ali samo u slučaju da se neutralna os poprečnog presjeka nalazi u pojasnici. Razlika je samo u proračunu početnog stanja elementa prije ojačavanja.

\section{$4 \quad$ Primjer proračuna}

Potrebno je ojačati pravokutni $A B$ poprečni presjek dimenzija $\mathrm{b} / \mathrm{h} / \mathrm{d}=30 / 50 / 45 \mathrm{~cm}$ pomoću CFRP lamela $\left(E_{f u}=\right.$ $\left.165000 \mathrm{~N} / \mathrm{mm}^{2} ; \varepsilon_{\mathrm{Uu}}=0,007\right)$ koje se lijepe na donju plohu. Razred betona je $\mathrm{C} 25 / 30$, a armatura je kvalitete B500B, i to: vlačna armatura $3 \phi 20\left(A_{\mathrm{s} 1}=9,42 \mathrm{~cm}^{2}\right)$ te tlačna armatura $2 \phi 14\left(A_{\mathrm{s} 2}=3,08 \mathrm{~cm}^{2}\right)$. Moment savijanja prije ojačavanja presjeka iznosi: $M_{0}=52,88 \mathrm{kNm}$, a onaj na koji se ojačava poprečni presjek iznosi: $M_{\mathbb{E}}=279,39$ $\mathrm{kNm}$.

Konačni koeficijent puzanja jest: $\varphi\left(\infty, t_{0}\right)=2,4$ pa je efektivni modul elastičnosti betona:

$$
E_{\mathrm{c}, \mathrm{eff}}=E_{\mathrm{cm}} /\left(1,0+\varphi\left(\infty, t_{0}\right)\right)=8970,6 \mathrm{~N} / \mathrm{mm}^{2}
$$

Omjer modula elastičnosti betona i čelika: $\alpha_{s}=E_{\mathrm{s}} / E_{\mathrm{c}, \mathrm{eff}}=200000 / 8970,6=22,3$

Položaj neutralne osi za raspucali poprečni presjek prema izrazu (7): $x_{0}=17,9 \mathrm{~cm}$

Moment tromosti raspucalog poprečnog presjeka za stanje prije ojačavanja prema izrazu (9) iznosi:

$$
I_{\mathrm{c} 0}=222545,1 \mathrm{~cm}^{4}
$$

Relativna deformacija tlačnog ruba poprečnog presjeka prema izrazu (8) iznosi: $\varepsilon_{\mathrm{c} 0}=4,74 \cdot 10^{-4}$, dok relativna deformacija vlačnog ruba poprečnog presjeka prema izrazu (10) iznosi: $\varepsilon_{0}=8,5 \cdot 10^{-4}$.

Proračun relativne deformacije CFRP lamele nakon ojačanja:

$$
\begin{gathered}
M_{\mathrm{Ed}}=f_{\mathrm{cd}} \cdot \alpha_{\mathrm{v}} \cdot b \cdot\left(\xi^{*} \cdot h\right) \cdot\left(h-k_{\mathrm{a}} \cdot \xi^{*} \cdot h\right)-A_{\mathrm{s} 1} \cdot f_{\mathrm{yd}} \cdot d_{1} ; \quad \alpha_{\mathrm{v}}=0,810 ; \quad k_{\mathrm{a}}=0,416 \\
27939=1,667 \cdot 0,810 \cdot 30 \cdot\left(\xi^{*} \cdot 50\right) \cdot\left(50-0,416 \cdot \xi^{*} \cdot 50\right)-9,42 \cdot 43,48 \cdot 5,0 \\
42128,42\left(\xi^{*}\right)^{2}-101270,25 \cdot \xi^{*}+29986,91=0 \\
\xi^{*}=\frac{|0,0035|}{\left|\varepsilon_{\mathrm{c} 2}\right|+\left|\varepsilon_{\mathrm{c} 2}\right|+\left|\varepsilon_{\mathrm{f}}\right|}=\frac{|0,0035|+\left|8,5 \cdot 10^{-4}\right|+\left|\varepsilon_{\mathrm{f}}\right|}{|0,35 \rightarrow| \varepsilon_{\mathrm{f}} \mid=0,00565<\varepsilon_{\mathrm{fu}}=0,007}
\end{gathered}
$$

Uvjet za maksimalnu visinu tlačnog područja (tablica 2): $\left|\varepsilon_{f}\right|=0,00565>0,005-\varepsilon_{f 0}=0,00415$ $\rightarrow$ zadovoljava. 
Proračun potrebne površine CFRP lamele: $A_{\mathrm{f}}=\frac{F_{\mathrm{c}}-F_{\mathrm{s} 1}}{\varepsilon_{\mathrm{f}} \cdot E_{\mathrm{fu}}}=\frac{f_{\mathrm{cd}} \cdot \alpha_{\mathrm{v}} \cdot b \cdot\left(\xi^{*} \cdot h\right)-A_{\mathrm{s} 1} \cdot f_{\mathrm{yd}}}{\varepsilon_{\mathrm{f}} \cdot E_{\mathrm{fu}}}$

$$
A_{\mathrm{f}}=\frac{1,667 \cdot 0,810 \cdot 30 \cdot(0,35 \cdot 50)-9,42 \cdot 43,48}{5,65 \cdot 10^{-3} \cdot 16500}=3,21 \mathrm{~cm}^{2}
$$

\section{Literatura}

[1] fib bulletin 14 - Externally boded FRP reinforcement for RC structures, July 2001.

[2] EN 1992-1-1, Eurocode 2 - Design of concrete structures; Part 1: General rules and rules for buildings, European Committee for Standardization, Bruxelles, December 2004.

[3] Sorić, Z;; Kišiček, T.: BETONSKE KONSTRUKCIJE 1, Projektiranje betonskih konstrukcija prema europskim normama EN. Skripta Građevinskog fakulteta, 2010./2011., Zagreb

[4] Narayanan, R.S., Beeby, A.: Designers Guide to EN 1992-1-1 and EN 1992-1-2. , Thomas Telford, 2005.

[5] fib Bulletin 40 - FRP reinforcement in RC structure, September 2007.

[6] Pavić, K.: Ojačavanje armiranobetonskih konstrukcija proizvodima od polimera armiranog vlaknima, diplomski rad, Sveučilište u Zagrebu, Građevinski fakultet, 2012. 